\title{
An Analysis of Symbols Object in the Serarang Ritual in Melanau Community
}

Noor Norazila Inai, Mohamad Maulana Magiman, Norhuda Salleh

To Link this Article: http://dx.doi.org/10.6007/IJARBSS/v12-i1/11696

DOI:10.6007/IJARBSS/v12-i1/11696

Received: 05 November 2021, Revised: 07 December 2021, Accepted: 29 December 2021

Published Online: 11 January 2022

In-Text Citation: (Inai et al., 2022)

To Cite this Article: Inai, N. N., Magiman, M. M., \& Salleh, N. (2022). An Analysis of Symbols Object in the Serarang Ritual in Melanau Community. International Journal of Academic Research in Business and Social Sciences, 12(1), $1001-1016$.

\section{Copyright: (C) 2022 The Author(s)}

Published by Human Resource Management Academic Research Society (www.hrmars.com)

This article is published under the Creative Commons Attribution (CC BY 4.0) license. Anyone may reproduce, distribute, translate and create derivative works of this article (for both commercial and non0-commercial purposes), subject to full attribution to the original publication and authors. The full terms of this license may be seen at: http://creativecommons.org/licences/by/4.0/legalcode

Vol. 12, No. 1, 2022, Pg. $1001-1016$

Full Terms \& Conditions of access and use can be found at http://hrmars.com/index.php/pages/detail/publication-ethics 


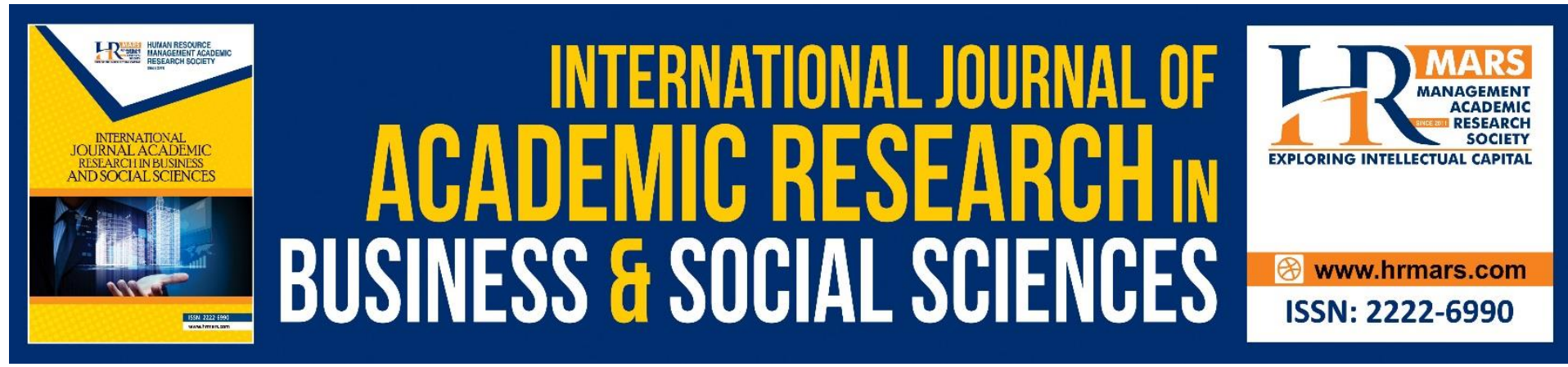

\title{
An Analysis of Symbols Object in the Serarang Ritual in Melanau Community
}

\section{Noor Norazila Inai ${ }^{1}$, Mohamad Maulana Magiman ${ }^{1}$, Norhuda Salleh ${ }^{2}$}

${ }^{1}$ Faculty of Humanities, Management and Science, Universiti Putra Malaysia Kampus Bintulu Sarawak (UPM), Jalan Nyabau, 97008 Bintulu, Sarawak, ${ }^{2}$ Faculty of Social Science and Humanities, Universiti Malaysia Sabah (UMS) Jalan UMS Kota Kinabalu Sabah

Email(corresponding author): mdmaulana@upm.edu.my; norhudasalleh@ums.edu.my

\begin{abstract}
The Serarang ritual is an annual ritual that must be performed by the Melanau Likow community in preparation for the new year. Tama Kaul is the main leader in the implementation of this ritual with the use of symbols in the form of objects. Each object used contains a specific meaning, interpreted and agreed upon by its practicing community. The local wisdom possessed by this community of practitioners is inherited from one generation to another. Till this day, the practicing community still clings to the beliefs they inherited even although some of them have converted from their original religion. Therefore, this study aims to analyse the meaning of object symbols in the implementation of Serarang rituals. This study used an ethnographic approach through participatory observation, recording and photographic methods as well as a series of interviews with Tama Kaul and the ritual practitioners. The study location was located in Kampung Medong, Dalat Sarawak. Data analysis found that there were five object ritual symbols used to accompany the Serarang ritual namely kubo beliseng, beliseng, dian, the blood of rooster's feet and percak cloth. Among the meanings of symbols supported by these object symbols are the meanings of respect, purity, prayer and hope, peace between the two worlds and love. The results of this study also found that this ritual is still practiced by the Melanau Likow community until this day and becomes the identity of their existence in Sarawak.
\end{abstract}

Keywords: Symbol, Ritual, Serarang Ritual, Melanau Likow, Ethnography

\section{Introduction}

Melanau is the fourth largest bumiputera in Sarawak after Iban, Malay and Bidayuh, and occupies areas in the heart of Sarawak. According to Amir (2005), the Melanau can be defined as people who practice the Melanau culture, speak the Melanau language, eat the Melanau food and have the Melanau identity, as well as live in the coastal areas between Kuala Rejang and Kuala Baram. Most Melanau people also live in coastal areas since the $16^{\text {th }}$ century which are usually located at the mouth of major rivers near the beach or coastal areas or they form villages in groups or parallel as in the areas of Igan, Matu, Daro, Mukah, Balingian and Bintulu. 
The Melanau called themselves as a-likow which means indigenous or native people, although the terms a-likow also refers to the Melanau people who still practice the pagan religion.

The Melanau Likow community defines the world as a vague cosmos full of mystery. They believe that every natural form and object around them has extraordinary spirit and strength. According to Yasir (1987), the Melanau Likow community believes that important questions in life are often associated with supernatural things that are difficult to see through the eyes of ordinary human beings. For example, the beliefs in mystical elements such as believing in the existence of ghosts, genie, goblins, storms, hurricanes and the things that terrify them around them. This belief system is translated through various taboos, customs and rituals that become practices in their daily lives.

Serarang ritual is the 'parent' ritual in the community's life tradition based on the beliefs of animism. This ritual also is a religious tradition that must be carried out in January every year as a symbol of gratitude to Ipok, the god of rivers and seas for the abundance of sustenance given during the previous year, as well as seeking protection from all disasters and calamities. According to the cosmology of the Melanau Likow community, the source of livelihood comes from Ipok which is an extraordinary force responsible for controlling and caring for the universe. According to Mohamad Maulana et al (2019), the relationship between the nature and man is inseparable because it possesses high sacred values in which the existence of a spirit or soul that has supernatural power controls this universe. The existence of this spirit or soul is difficult to see with the naked eye or the common man and has become part of the Melanau Likow cosmology to ensure that this supernatural spirit is taken care of, not disturbed and not invaded by their abode. According to the beliefs of the Melanau Likow people, the Kaul ceremony would not be perfect without the Serarang ritual. In the performance, symbols in the form of objects are used to calm Ipok in addition to the recitation of prayers and mantras by Tama Kaul. Therefore, this research was done to analyse the meaning of the object symbols used to accompany the Serarang ritual of the Melanau Likow community in Dalat Sarawak.

\section{The Origin of the Melanau People}

Melanau are indigenous people with the majority live in the central part of Sarawak, Malaysia. They are called by various names and spelling by the Western writers and researchers. A research by Morris (1953) titled 'A Melanau Sago Producing Community in Sarawak' stated that the word Melanau has existed in European maps since 1595 when the word 'Melanau' has been called as 'Millanows' (Keppel, 1968), 'Millanowes' (Low, 1968), 'Milanos' (Roth, 1968), 'Milano' (Clyare, 1971) and 'A-Liko' (Morris, 1953, 1971). The Malays of Sarawak call the Melanau as 'Melano' while the Iban community calls them as lawut. Lawut according to Bedui (1981) literally means 'people who live in estuary'. Besides, Morris also added that the terms Melanau Likow or 'A-Liko' means people from the riverside areas, just how the Melanau people in the area of Sungai Mukah and Sungai Oya call themselves A-Liko Mukah and A-Liko Oya as according to the name of the river closest to their areas. However, according to Dzulfawati Hassan (2006), the terms 'Likow' in the Mukah area is used to distinguish themselves (pagan Melanau) with Islamic Melanau and Christian Melanau. In earlier colonial times, the group that still practiced this traditional belief was known as "Melanau Pagan" or "Melanau Likow". The term A-Liko is solely based on the settlement of the community with most of them live in inland, the banks of the Rajang River, and riverine areas. Thus, the 
existence of the Melanau Likow community is very closely associated to practices at rivers and seas that ultimately translated into their artistic culture. Data by Rensch (2012) showed the population of the Melanau community is increasing around 130,800 people covering part of Mukah and heading towards the coastal region of the Rajang Delta to the Balingian river (see Table 1).

Table 1. General information about the Melanau Likow community

\begin{tabular}{ll}
\hline Ethnic & Information \\
\hline Melanau Likow & Bahasa Malaysia (Sarawak) ISO 639-3: spg. Populasion:130,800 \\
& (Sarawak state data, 2019)121,220 (Ethnologue) \\
& Region: Mukah Division, the coastal region of the Rajang Delta towards \\
& the Balingian river \\
& Other names: Belana'u, Milanau, Milano \\
& Dialect: Mukah-Oya (Muka, Mukah, Oga, Oya, Oya '), Balingian, Bruit, \\
& Dalat (Dalad), Igan, Sarikei, Segahan, Prehan, Segalang, Siteng. The \\
& Balingian dialect differs linguistically.
\end{tabular}

Source: Rensch (2012)

\section{Literature Review}

Symbols are the simplest language to describe meaning through actions in rituals performed by the practicing community. Symbols have the uniqueness of explaining in more depth about sacred things that are not easy to explain with the understanding of the naked human eye. According to Mary Douglas (1970), symbols are the simplest tool to convey the meaning behind a ceremony or ritual. According to her, human beings are the ones who are responsible for creating the meaning behind every social behaviour and will determine that each behaviour and the meaning of the symbol is accepted or otherwise in the society. Symbol-related study was developed by Salleh (2018)stating that the symbols in a ritual are used as a source to convey the intended desire through performance whether through verbal or non-verbal communication. In addition, symbols also play a role in conveying meaning through interaction between the presenter and the recipient of a message.

According to Magiman (2012), rituals are designed to free oneself, family and society from the shackles of a society's life problems. Thus, rituals are carried out as a transformational tool to deal with the crisis of human life itself which is constantly faced with risks and challenges. The behaviour in the ritual is then translated through symbols and various forms of ritual that are only understood by the community of its practitioners in the process of unification between man and the supernatural powers recognized by the community of its practitioners. This statement is in line with the findings obtained by Tugau et al (2021) that a ritual is a performance carried out according to regulations and agreed upon by the practicing community in the process of unification between humans and the supernatural beings who have supernatural powers. Therefore, the expressions of prayers, incantations and symbols regardless of food or object are used in the conduct of a ritual to communicate and reconcile with the supernatural powers.

In research by Nasir et al (2016), symbols in the form of objects are used as instruments of worship and obedience to the spiritual powers believed to be sacred and special. Primitive societies believed that by storing and wearing such artifacts, they could 
indirectly bring profit, luck or escape danger and disaster (Afandi, 2018). Based on Derlon et al (2010), the sacred understanding of objects believed to have extraordinary power in human beliefs and culture has been an academic debate since the $19^{\text {th }}$ and early $20^{\text {th }}$ centuries, when anthropological researchers are attracted to spiritual phenomena related to rituals, religions, human understandings and ideas to connect with supernatural powers. According to Hodder (1994) in Hodder (2013), symbols in the form of objects are categorized in several perspectives that have value through their influence towards the world, have meaning and symbolism in a social communication, and achieved through the mixing of the past either through cultural or historical assimilation. Thus, the symbol of the object used as an intermediary to the supernatural powers contains a sacred element capable of protecting society from any calamities and catastrophes.

Based on Taylor (1871) in Shook et al (2016), animism generally refers to a doctrine of spirit and spirit. Animism is also a belief about soulful beings other than human beings which encompasses two forms namely the belief that human beings have an eternal soul after death and the belief that souls also exist in other beings. Zamzuri et al (2019) in their research regarding religions and beliefs have discussed about the belief of animism that circled the entire life of the Mah Meri community before the advent of religion. The main elements expressed in the animistic beliefs of this society involve supernatural beings, taboos, spirits, magic, spirits and shamans. This belief is the belief and the practice of the Mah Meri community in every corner and space of the world. They believe that spirits and souls exist in various types and forms such as guardians, ghosts, goblins and hobgoblins. In fact, the Mah Meri community also believes that there is a classification of spirits which is divided into evil spirits and good spirits. Thus, this belief of animism has given birth to certain rituals to expel evil beings or with the aim of establishing a harmonious relationship between the villagers with the spirits of good supernatural beings. According to him, the rituals carried out are completed with the recitation of mantras by the shaman by serving food and items to the subtle beings such as kuih apam, candles, water spells, chicken eggs and grains.

Therefore, in order to understand the meaning of a symbol, it is necessary to interpret the symbol systems in their specific forms as they are contained in their specific social context. This is because symbols serve as a mechanism to convey a message or one way to communicate (Shokeran \& Magiman, 2019).

Mohamad Maulana (2012), menyatakan bahawa ritual adalah merupakan alat transformasi dalam sesebuah masyarakat dan setiap persembahan-persembahan ritual akan mengandungi unsur-unsur simbolik. Setiap perlakuan atau persembahan yang dijalankan adalah mengikut peraturan sosial yang telah dipersetujui di kalangan masyarakat tersebut dan akan menentukan sama ada perlakuan itu akan menjadi berkesan atau tidak. Perlakuan-perlakuan yang terdapat di dalam persembahan itu adalah merupakan simbol dalam proses penyatuan pemohon kuasa (manusia) dan pemberi kuasa (kuasa luar biasa atau kuasa ghaib oleh Alexander Peter Chelum (2021)

\section{Research Methodology}

This study was conducted at the selected study location, which was located in Kampung Medong, Dalat Sarawak where the community is still firmly practicing Serarang rituals to this day. This study was conducted from January 2019 until December 2020. This study was conducted using a qualitative method with an ethnographic approach that was based on 
participatory observation, video recording and photography methods. Besides, a series of interviews was also conducted with informants such as Mr. Ceylon bin Asat, 67 years old, the chief village of Medong, Dalat Sarawak; Mr. Mumui bin Atin, 72 years old, a Tama Kaul or the ritual leader; Mr. Mahrob bin Libong, the chief village of Kampung Medong Hilir, 52 tahun; Mrs. Catherine Nas binti Mukit, 76 years old.

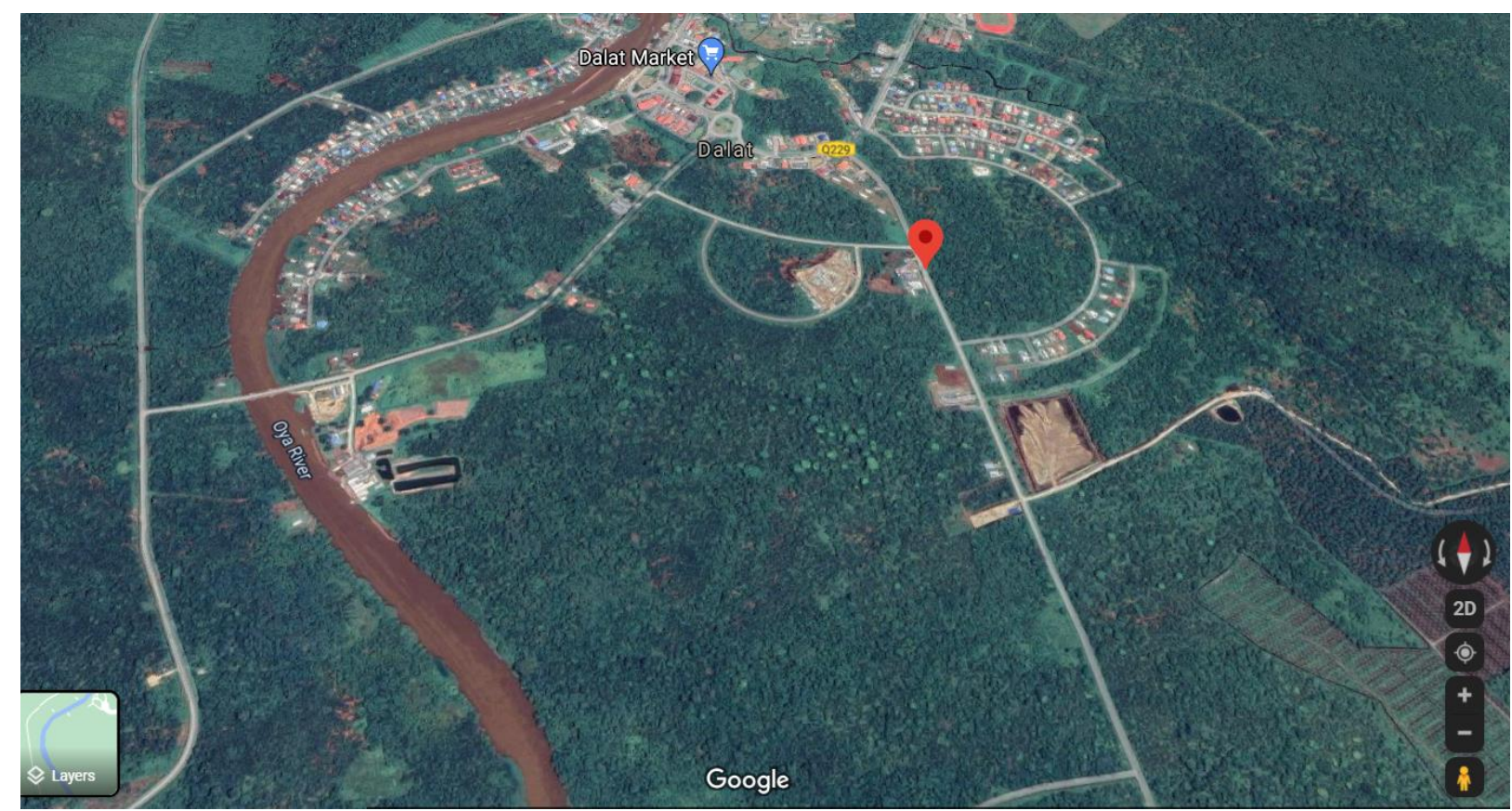

Map 1: Map of Dalat area and study location

Source: Kampung Medong, Dalat Sarawak; google map.

The study data obtained were analyzed using the Symbol Ritual Model (MRS) to analyze the meaning of object symbols used by the Melanau Likow community throughout the implementation of the Serarang ritual. Analisys data using Symbol Ritual Model (Inai, 2022) consisted of five main elements namely the element of animism (Melanau Likow), the element of religion (Christian and Muslim Melanau), the element of syncretism, the palei asel principle and the existence of Ipok. 
Figure 1. Symbolic Ritual Model (MRS) Framework

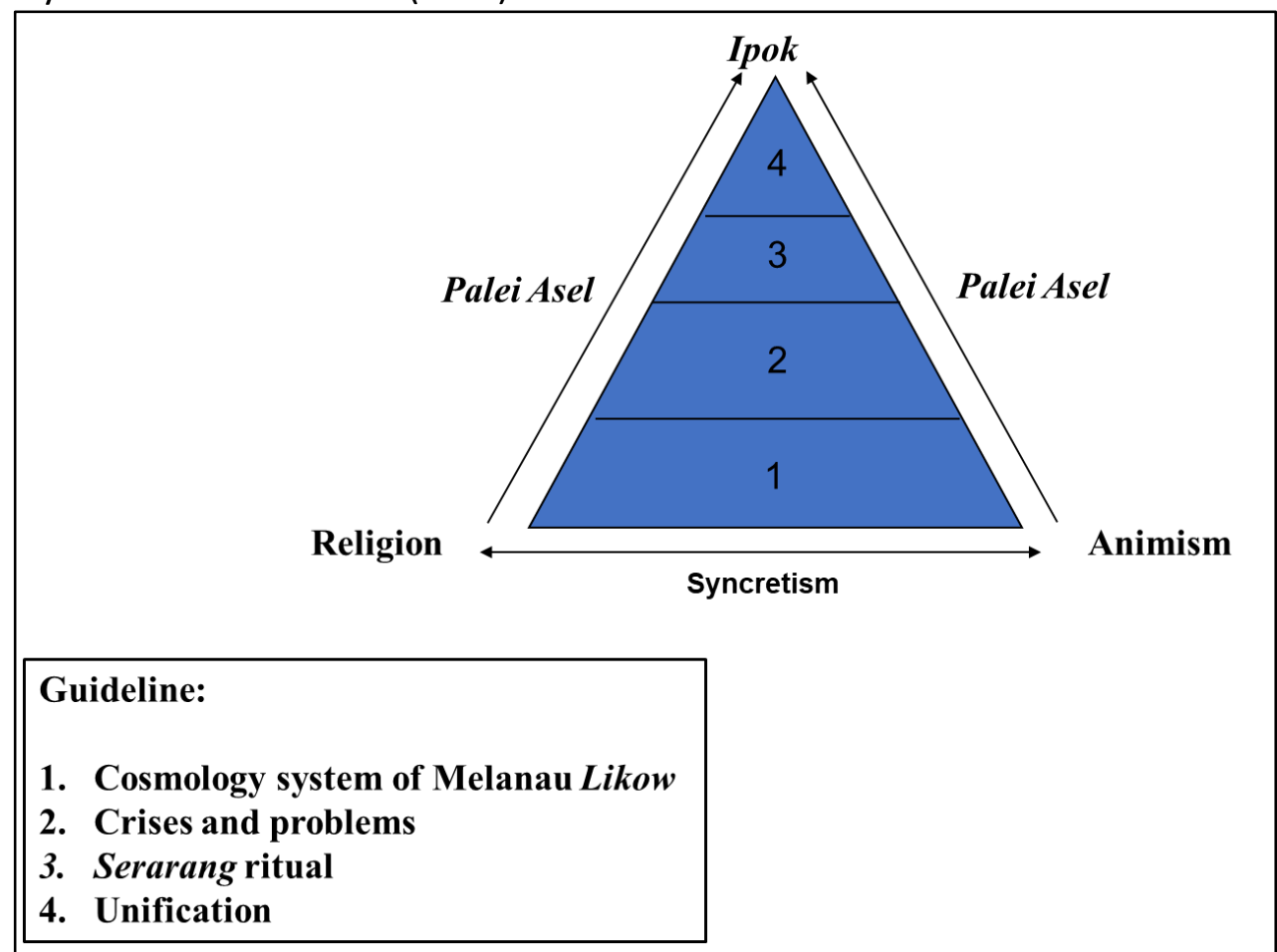

Source: Inai (2022)

Based on the Symbolic Ritual Model (MRS) framework, there are four specific levels to achieve the desired goal and perfection in the Serarang ritual. The first level is the cosmological system of the Melanau Likow community which is still based on the beliefs of animism practiced for generations. They believe that if the wishes of these supernatural beings are not fulfilled first, then the revenue from rivers and seas will also decrease in addition to getting all the misfortunes or disasters that will befall their lives. These crises and problems are often associated while on river and sea because the Melanau Likow community is focused on economic life that based on the river and sea sources. Therefore, to solve the related problems, the Serarang ritual is carried out in response to the crises. In the process of performing this Serarang ritual, symbols in the form of objects are used to accompany the ritual performed to Ipok. Therefore, the level of unification is seen through the merger between Melanau Muslim, Melanau Christian and Melanau Likow communities who carry out this Serarang ritual together for the common good so that the protection and the harmony of the village can be maintained and preserved.

All these levels are united by the palei asel princple until there is a process of syncretism by the Melanau community which consists of Melanau Likow, Melanau Muslim and Melanau Christians through the involvement of religious people and Tama Kaul as the head of ritual. The Palei principle is a belief that if a person violates the taboos set by the heritage of previous traditions, then he will get a plague, bad luck, curse or accident. By adhering to this belief, any difference in the life of the Melanau community can be bound by mutual recognition, respect, acceptance, sharing and celebrating together. According to Amir (2000), the main cosmological cores of Melanau society focuses on three questions namely God, nature and man. These three cores are inseparable from each other because every question of nature and man is inseparable from its connection and implication with divinity. 
Therefore, the use of object symbols in Serarang rituals would be analysed using the Symbol Ritual Model (MRS) framework to unravel the meaning behind their uses.

\section{Study Findings and Discussion}

The Serarang ritual is the culmination in the life of the Melanau Likow community where it is coloured by various forms, customs and certain taboos. This is also stated by Amir (2000) in his writing entitled "Kaul Memujuk Ipok" that is when Ipok is served, the residents believe that Ipok will be able to provide a peace, tranquility and harmony to the individual who requests it. Besides, these rituals incorporate various forms of rituals into them that associate human life with elements of nature and animism. When this ritual is performed, there are object symbols used namely beliseng, kubo beliseng, dian, chicken blood and percak cloth. The symbols of these objects contain meanings that are translated according to the cosmology of their society. According to Magiman (2012), symbols become a sign of genuine sensitivity, born to recall something special as a meaning giver to the life of a society.

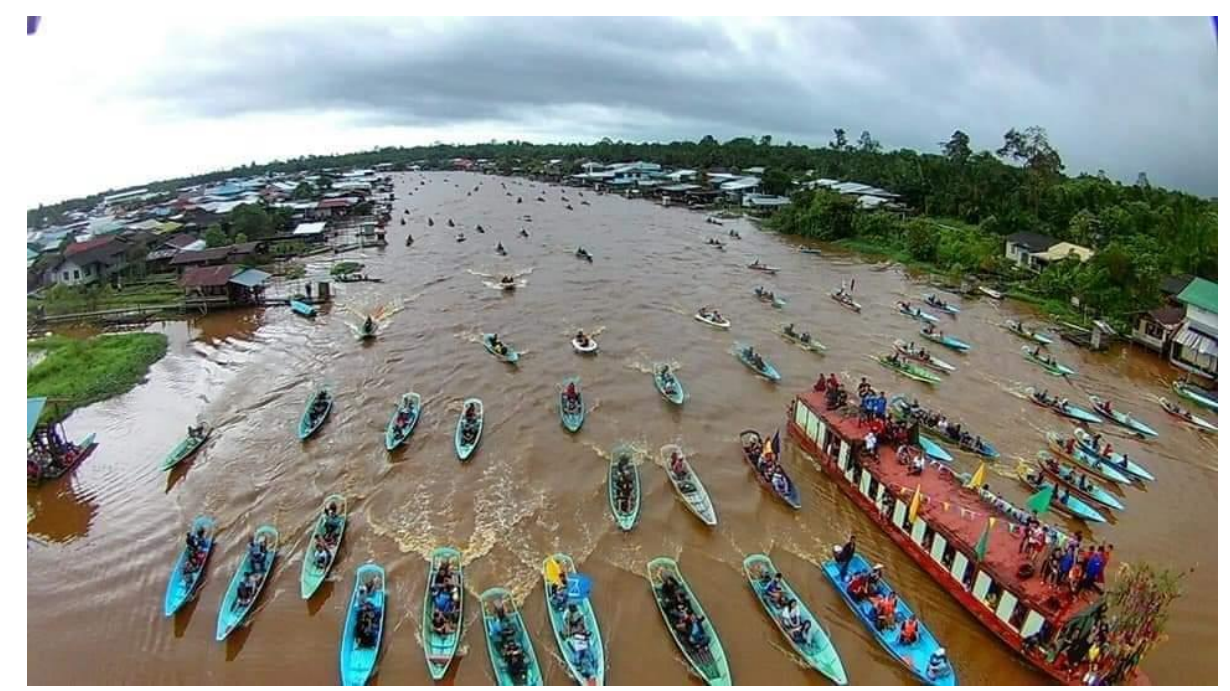

Figure 1: Serarang ritual attended by Melanau community in Kampung Medong. Source: Fieldwork, 2019.

Based on the results of data analysis using the Symbol Ritual Model (MRS), there are five symbol meanings in the Serarang ritual are respect, purity, prayer and hope, reconciliation of the two worlds and love. 


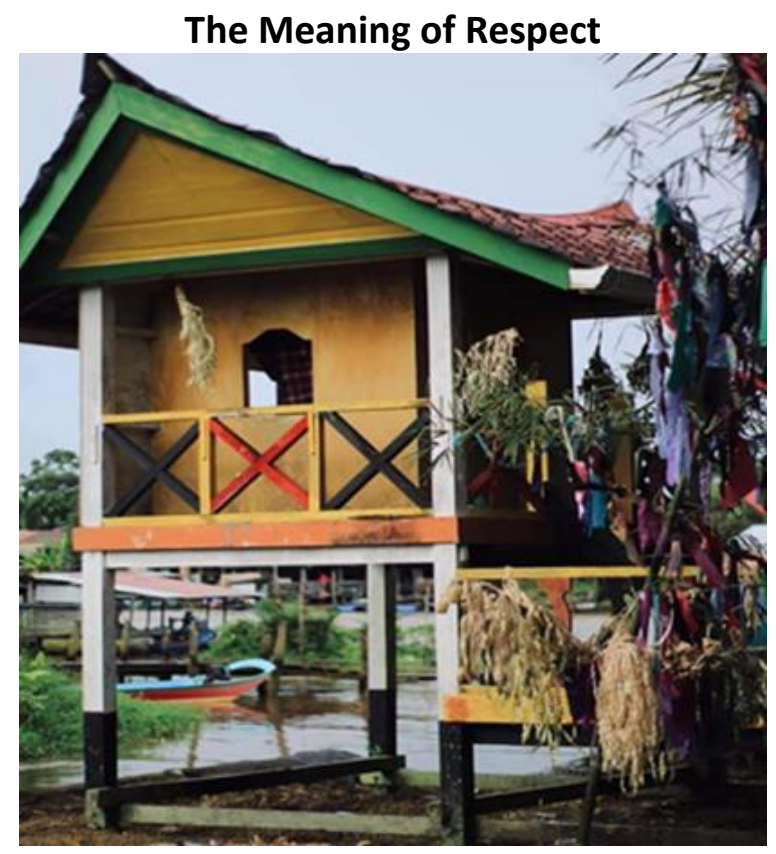

Figure 2: Kubo Beliseng which symbolizes respect to Ipok.

Source: Fieldwork, 2019

Respect is the feeling of respect and submission to supernatural beings who are believed to have extraordinary powers. In the context of the Serarang ritual performance, the meaning of respect is clearly seen through the symbol of kubo beliseng which is the symbol of the highest respect of the Melanau Likow community to the supernatural being they respect, namely Ipok. In the first level of the Symbol Ritual Module (MRS) which is the cosmological floor of Melanau Likow, the symbol meaning of respect is illustrated through the ritual of bathing and cleaning the beliseng kubo which is believed to be the highest 'guest' house in the Serarang ritual. Through the animistic beliefs of the Melanau Likow community, beliseng kubo must be cleaned and bathed in the morning before the Serarang ritual every year. To lead this ceremony, only Tama Kaul is allowed to be an intermediary among humans to interact with Ipok. Tama Kaul is a person who is highly respected and revered in the social community of Melanau Likow. Therefore, Tama Kaul is chosen among the Pagan or A-liko men, of Sepok descent (those of pure blood), recognized for his wisdom on the customs and the culture of the Melanau people. According to Jeniri Amir (2000), Tama Kaul is a traditional elite leader who is the main pillar responsible for persuading and appealing to Ipok, banishing all evils and calamities that may befall mankind, ensuring that all taboos are observed and even has the power to punish anyone who disobeys. Kubo beliseng should be bathed and cleansed by Tama Kaul with the blood of rooster's feet, seven candles, Icang ornaments and accompanied by the expression of incantation to summon the spirit of Ipok to together bless the rituals performed. Before bathing kubo beliseng, Tama Kaul will greet and say a spell as an opening verse to Ipok. In the verses, the good Ipok is expected to continue protecting them while evil spirits such as devils and satans are asked to return to their places of origin no matter they come from land, river or sea. This is because the Melanau Likow community believes that the world is inhabited by Ipok according to the area that has been set, which is divided into sky, land and water. Only after that, a food offering is served to Ipok as a sign of respect for Ipok's presence together in the rituals performed. Similar with the practice of the religious community which consists of Melanau Christian and Melanau Muslim, the concept of respecting and honoring the guests is also seen clearly when various of foods are prepared 
to be eaten together with other communities during the ritual. It is a symbol of respect to Ipok who bestows an abundance of sustenance to be shared together so that blessings can be obtained. Based on an interview with Tama Kaul, the Melanau Likow community believes that human beings who respect kubo beliseng will have a peaceful life in this world and in the afterlife.

\section{The Meaning of Purity}

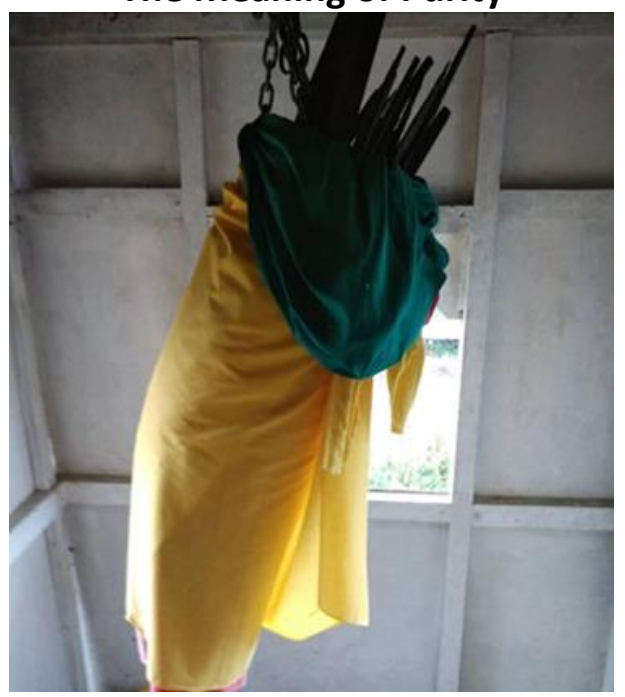

Figure 3: Beliseng which symbolizes the meaning of purity in the cosmology of Melanau Likow community.

Source: Fieldwork, 2019

Beliseng is a sacred object kept in a wooden container consisting of nyipan buou or demon teeth, magic stone or spirit stone, spear and wrapped in cloth measuring 2 feet long and 4 feet circumference. In the Symbol Ritual Module (MRS), the animistic belief practices of the Melanau Likow community are translated through the purity symbol of beliseng. Based on the interviews with Tama Kaul and several ritual practitioners, beliseng water is used for purification of themselves and the whole village. According to the beliefs of this community, beliseng water is believed to be able to cure strange diseases that infect his community. Therefore, when there are individuals who have strange diseases such as skin diseases, measles, prolonged fever and feel lifeless in carrying out daily activities, they will be bathed with beliseng water. This is because beliseng that contains magic stones or spirit stones can cure any disease and restores the peace of the village from disasters and catastrophes. In addition, the purity meaning of beliseng is also contained in the verses of prayers and mantras recited by Tama Kaul. The mantras revealed are poetic words used to persuade and to appeal Ipok. However, the mantra cannot be given arbitrarily to others except those who are of Sepok descent, Likow religion and with a predetermined amount of pengeras. This matter is also stated by Amir \& Pawi (2001) in Morris (1953) that only Tama Kaul can be an intermediary for humans to communicate with Ipok through the recitation of prayers and mantras. Therefore, the meaning of the purity of beliseng is clearly seen in the process of purifying the community from any disease as well as purifying the whole village from all calamities. Based on an interview with Tama Kaul, the beliseng objects need to be taken care of, cleaned and preserved so that all evil elements will not interfere with community life. 


\section{The Meanings of Prayer and Hope}

Hope is one of the symbolic meanings depicted through the symbol of the candle object found in the Serarang ritual. Hope is a prayer or a desire to make something come true. According to the beliefs of the Melanau Likow community, the white smoke from the flame of a candle serves as a tool to convey the hopes raised to Ipok. The Melanau Likow community believes that the white smoke floated along with the prayers and the hopes expressed to Ipok. In fact, the use of white candlesticks signifies the purity of prayers that are expressed verbally or nonverbally to Ipok. According to Sharma (2012), the white color symbolizes purity and serenity to an individual. Therefore, the use of white candlesticks is translated through the purity of prayer and the hope that is raised in the new year so that the coming year will be blessed with more abundant sustenance as well as protection while earning a living in rivers and seas.

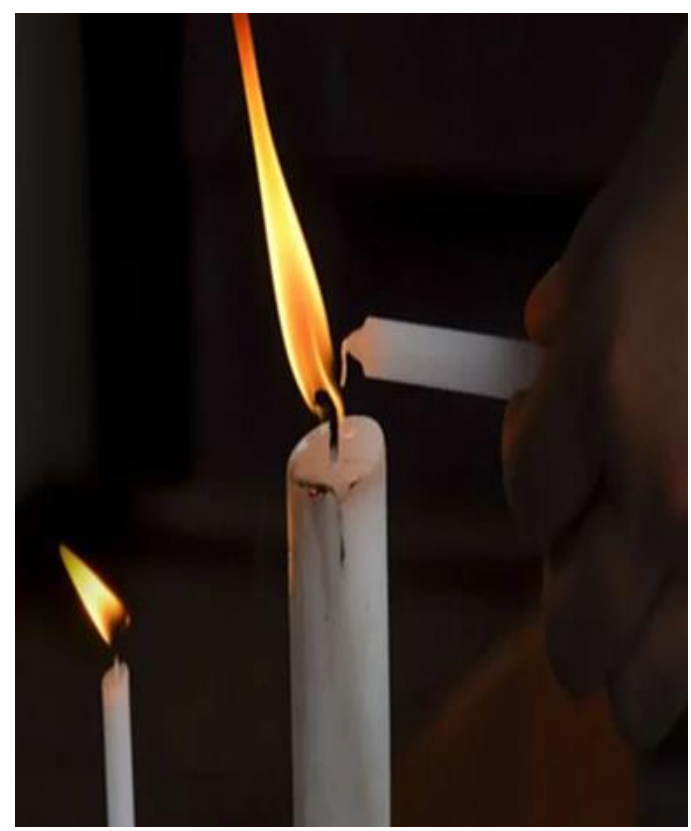

Figure 4: Dian which symbolizes prayer and hope.

Source: Fieldwork, 2019

In addition, the Melanau Likow community also believes that the dian light symbolizes human liberation from the shackles of the world's darkness. Based on the interview with the chief village of Kampung Medong, Mr Ceylon bin Asat, seven dian candles are lit around kubo beliseng before the preformance of Serarang ritual as a sign of man begs to be freed from all the shackles of the darkness of the world and hopes that the light will always illuminate the life of his whole society. Thus, the people of Melanau Likow hope that their lives will be like dian light that always illuminates the darkness and hope that life will always shine like the light of dian. 


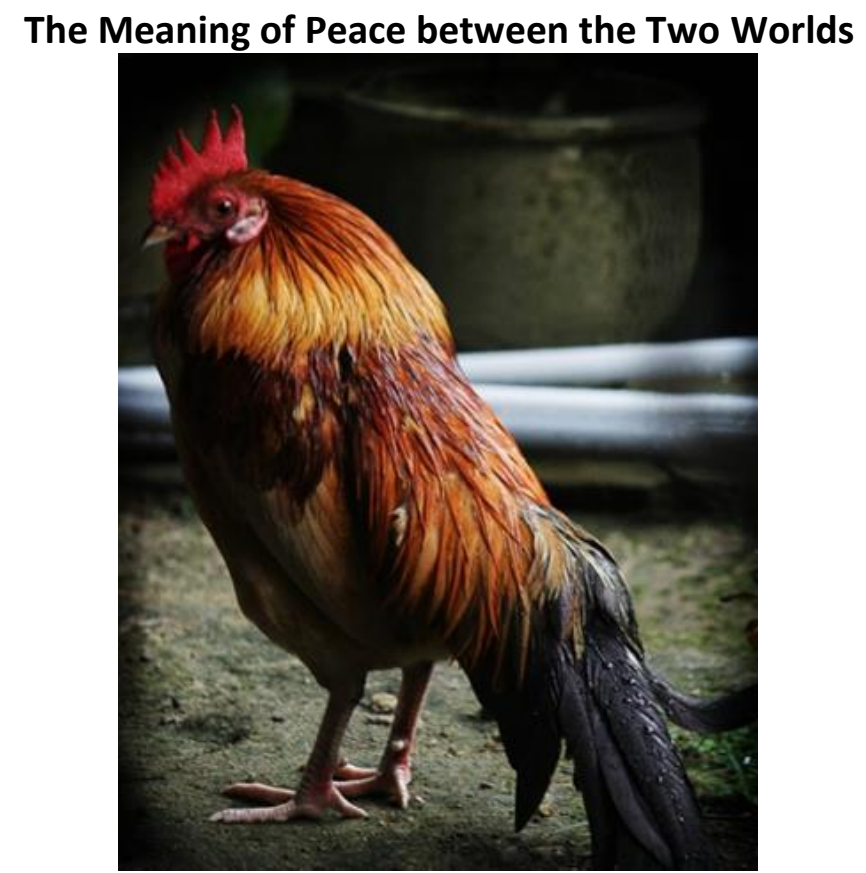

Figure 5: Chicken which carries the symbolism of the peace between the two worlds. Source: Fieldwork, 2019

Chicken carries its own symbolic meaning in the life of the Melanau Likow community. According to the cosmology of the community, the chicken symbol brings great good luck. According to Kassim \& Zakaria (2021), chicken in Malay culture is used in many religious functions because it is said to be a pet that brings many sources of livelihood. The same matter is stated by Sanjaya (2021) in his research regarding Manggarai (Timur) community in Flores, Indonesia who also uses the symbol of rooster as an offering to God. Chickens are symbolized as animals that take great care of their area or territory because of their very strong and loyal nature to be in their area. Based on the interview with informant which is Mr. Pateran Lebai, the blood of the rooster's feet is used as a reconciliation between the two realms, namely between humans (world realm) and Ipok (supernatural realm) in the Serarang ritual. This is related to the Melanau Likow cosmological system which believes that the world is not only inhabited by humans but there are beings other than humans who have souls and spirits. Therefore, they believe that the spirit of Ipok is also divided into two elements namely the elements of good and evil. To bring peace between man and the element of evil spirits such as duhig, tow, genie dan amow, the blood of the rooster's legs will be taken before being released again because in the tray sent to Ipok, any bloody things are not allowed to be served to Ipok. It becomes a major taboo in the Serarang ritual because no element of animal slaughter is allowed to be carried out during the ritual until three days after the ritual took place. This is because the Melanau Likow community believes that if anything bloody is served to Ipok, it is feared that Ipok will feel addicted and wander around looking for other victims. It is feared that this will bring misfortune and accidents to human beings. This is in line with the palei asel belief found in the Symbol Ritual Model (MRS) which is a taboo held by the entire Melanau community so as to create an element of syncretism in the community. In addition, the blood of the rooster's feet is also rubbed on the pillars of kubo beliseng as a symbol of welcoming the spirit of beliseng. This act is called peda' lebok or bleed the house to awaken the spirit of Ipok which signifies peace between Ipok and man. At the same time, any evil elements will be banished so as not to approach human beings and their lives in the new coming year. According to Mr. Mumui bin Atin as the Tama Kaul which was interviewed in his house on 30th December 2019, "the red colour is the colour of blood, the colour that symbolizes the birth of man into the realm of the world. The red colour is also the colour of the promise (blood) between humans and lpok". This is also in line with the results of a study obtained by (Sharma, 2012) Neena Sharma (2021) when the red colour is also expressed as the colour of blood and has magical powers that can lead to good. Thus, when the spirit of Ipok is 
resurrected using the blood symbol of the rooster's foot, the Melanau Likow community believed peace would be able to be established by obtaining blessings from Ipok.

\section{The Meaning of Love}

Love is one of the symbolic meanings found in the Serarang ritual. According to Sugiyono (2017), love is one of the basic needs in a person's life. The symbol meaning of love in the Serarang ritual is seen through the percak cloth which is one of the object symbols used in the decoration of Serarang. According to Mrs Umang binti Aduk whom interviewed on $28^{\text {th }}$ December 2019, there is no colour determination for the percak cloth used including the use of black coloured fabric. The use of colourful cloth is translated through the symbol of the love bond despite different backgrounds of beliefs and religions practiced by the Melanau communities but still united on the basis of the palei asel principle. Therefore, during the process of tying the percak cloth around Serarang, the Melanau Likow, Melanau Muslim and Melanau Christian communities will recite prayers according to their respective beliefs as a sign of love among human beings.

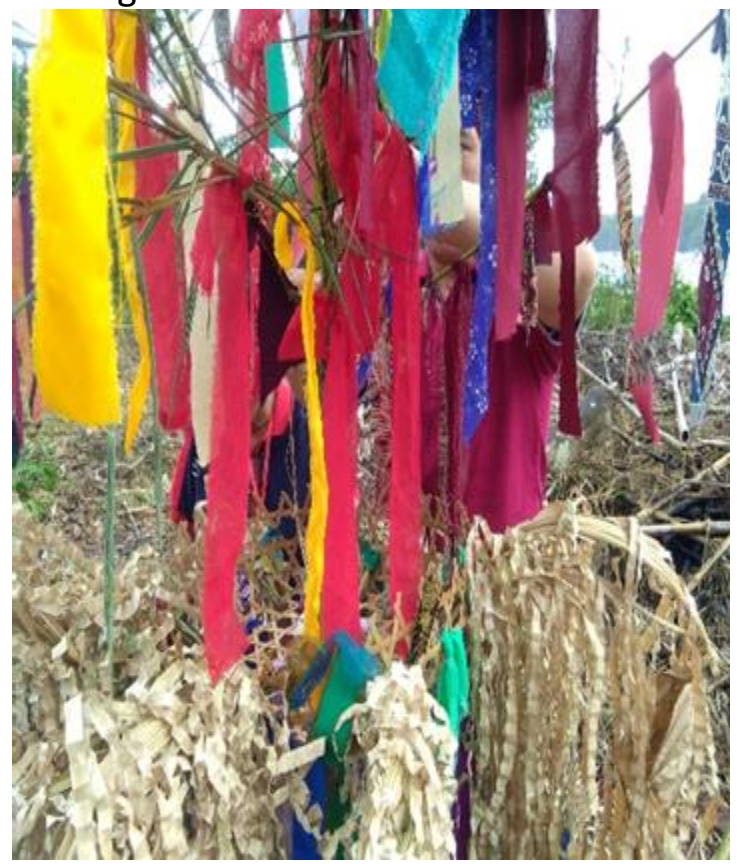

Figure 6: Percak cloth which represents the meaning of love.

Source: Fieldwork, 2019.

The meaning of love through the use of percak cloth is also translated through the expression of mantras by Tama Kaul while the cloth are tied around Serarang. Among the verses of the mantra recited by Tama Kaul are;

"Oi Ipok, Tujuan melo menyabek tageplah ikatan kasih sayang nua, Tohlah diak-diak, Bak sama-sama ji telo, Terima kasih gak kelo Ipok

Puk aaaaaaa......

Translation:

"Oh god, we ask you to strengthen the bond of love Arrange well for us together, thank you Oh God

We beg Oh God"

(Source: Mr. Mumui bin Atin) 
In the context of the expression of prayers and mantras, Tama Kaul requests Ipok to strengthen the bond of love between human beings because with a close bond of love will be able to solve all crises and problems, especially when looking for revenues in rivers and seas. Therefore, with this patchwork tied on the Serarang pillar, the Melanau Likow community believes that it symbolizes the bond of love not only among human beings but also carries the symbolic meaning of the bond of love between human beings and Ipok. This intertwined love must be maintained for the well-being and the harmony of the Melanau Likow community in the future.

\section{Conclusion}

A study conducted in Kampung Medong, Dalat Sarawak has shown that the object symbols used to accompany the Serarang ritual are beliseng, kubo beliseng, dian, rooster's foot blood, percak cloth, icang dan pakar carry their meaning from the point of view of the Melanau Likow community. The observations and findings of the study obtained explain that the object symbols in the Serarang ritual play a role in conveying messages and interactions with their meaning. The translated meaning brings the memory of the Melanau Likow community to Ipok who is believed to dominate their lives in this world. Without the object symbols used in the Serarang ritual, the goal of performing this ritual will not be able to be carried out perfectly. Gratitude and submission to Ipok which cannot be expressed in words have been expressed through the use of symbols in the form of objects as an intermediary between humans and Ipok.

In the life of the Melanau Likow community based on the beliefs of animism, the cosmological system of the community has acknowledged the presence of a supernatural power known as Ipok. Looking at the Symbolic Ritual Model (MRS), the five elements such as animism (Melanau Likow), religious elements (Melanau Christianity and Islam), syncretism, palei asel principle, and the existence of Ipok play a distinct role in maintaining the well-being of the Melanau community through the Serarang ritual. Object symbols need to be perceived and understood in the social context of the society that practices them, because only in this way will the true meaning of the object symbols used to accompany the Serarang ritual by the Melanau Likow community be felt and understood. Thus, through this study, it can be concluded that a symbol is the core to the meaning of the ritual process carried out, which will eventually explain how these symbols contain certain meanings related to the culture of society. Thus, through this study, it can be concluded that a symbol is the core to the meaning of the ritual process carried out, which will ultimately explain how these symbols contain certain meanings related to the culture of society. This study is a simple sense, not only analyzes the food symbols and objects used in rituals but also unravels the meaning behind each symbol used.

Overall, the symbols used in a ritual play a role in shaping the thinking of a society. In addition, the meaning of the object symbol in the Serarang ritual is also produced through the definition and the translation of the community through the behaviour, the utterance, and the actions of the community group verbally or non-verbally. The Serarang ritual performed shows a very strong palei asel principle among the Melanau Likow community who strive to maintain their identity through this very unique ritual. In ensuring this culture and heritage continues to be preserved, various efforts need to be introduced so that these very unique customs and cultures can be preserved. One of them is through the preservation of 
the cultural heritage of this community which will eventually be able to cultivate the spirit of patriotism in the souls of the current generation. Therefore, it is hope that this study can help readers understand the Melanau Likow community which highlights their identity, culture, and way of life. Through it, it is hoped that this study can be a guide or platform towards a more in-depth study to document the Serarang rituals of the Melanau Likow Sarawak community.

\section{References}

Amir, J. (2000). Kaul Memujuk Ipok. Dewan Bahasa dan Pustaka.

Amir, J. (2005). Masyarakat Melanau di Sarawak (1st Editio). Institut Terjemahan \& Buku Malaysia Berhad.

Amir, J., \& Pawi, A. A. A. (2001). Kaul: Suatu Interpretasi Sosiobudaya (1st Editio). Massa Kasturi Management.

Chelum, A., Magiman, M. M., Tugau, M., Saufi, M., Bokhari, S., \& Salleh, N. (2021). The Nyangahant Ritual In The Culture Of Salako Community At Kampung Pueh Lundu, Sarawak. Turkish Online Journal of Qualitative Inquiry (TOJQI), 12(7), 4341-4351. https://www.tojqi.net/index.php/journal/article/view/4404

Douglas, M. (1970). Natural Symbol, Explorations in cosmology. Barrie \& Jenkins.

Hassan, D. H. (2006). Upacara Kematian Melanau Likow Di Sarawak. Universiti Malaysia Sarawak.

Inai, N. N. (2022). Makna Simbol Ritual Serarang Dalam Masyarakat Melanau Likow Di Kampung Medong, Dalat Sarawak. Universiti Putra Malaysia Kampus Bintulu.

Amir, J. (2000). "Kaul Memujuk Ipok." Dewan Bahasa Dan Pustaka.

Amir, J. (2015). Masyarakat Melanau di Sarawak. Institut Terjemahan \& Buku Malaysia.

Kassim, F., \& Zakaria, N. (2021). Functions of Plant in Malay Taboos. International Journal of Humanities, Philosophy and Language, 4(13), 59-77.

https://doi.org/10.35631/ijhpl.413005

Magiman, M. M. (2012). Simbol dalam Makan Tahun Masyarakat Kadayan, Sarawak. Jurnal Melayu, 9, 259-287.

Magiman, M. M., \& Yatim, O. (2012). Simbol dalam Makan Tahun Masyarakat Kadayan, Sarawak. Jurnal Melayu, 9, 259-287.

Rahman, Y. A. (1987). Melanau Mukah : satu kajian budaya. Dewan Bahasa dan Pustaka.

Rensch, C. R. (2012). Melanau and the Languages of Central Sarawak. In Electronic Survey Report 2012-011.

Salleh, N. (2018). Komunikasi Bukan Lisan: Simbol Sebagai Medium Pemakluman Dalam Adat Persandingan Masyarakat Melayu. Jurnal Komunikasi Borneo, 6, 18-19. https://jurcon.ums.edu.my/ojums/index.php/jkob/article/view/1575/994

Sanjaya, F. O. (2021). MAKNA SIMBOLIS RITUAL LEGHA KIWAN DALAM RITUS KELAS MASYARAKAT MANGGARAI TIMUR: KAJIAN ETNOLINGUISTIK. Jurnal Bahasa \& Budaya, Vol. 5(No 1). https://doi.org/10.22225/kulturistik.5.1.2744

Sharma, N. (2012). How do Colors Affect Communication?

https://eltweekly.com/2012/03/vol-4-issue-13-research-paper-how-do-colors-affectcommunication-by-dr-neena-sharma/

Shokeran, D. H. Q. H. A., \& Magiman, Mo. M. (2019). Ritual Dalam Upacara Gawe Padi Masyarakat Salako Di Daerah Sematan, Lundu Sarawak. International Conference on Social Sciences and Humanities 2019 (ICOSSH2019), 224-235.

http://psasir.upm.edu.my/id/eprint/76458/ 
Stephen, M. H. (1953). A report on a Melanau sago producing community in Sarawak. H.M Stationery Office.

Tugau, M., Magiman, M. M., Salleh, N., Yusoff, A. N. M., \& Permana, S. A. (2021). The Pelian Ritual In Sebauh District, Bintulu, Sarawak. Turkish Online Journal of Qualitative Inquiry (TOJQI), 12(5), 3859-3868. 